\title{
On the Stancu type bivariate approximation formula
}

\section{DAN MICLĂUŞ}

\section{ABSTRACT.}

In the present paper we establish the form of remainder term associated to the bivariate approximation formula for Stancu type operators, using bivariate divided differences. We also shall establish an upper bound estimation for the remainder term, in the case when approximated function fulfills some given properties.

Acknowledgment. I thank to the reviewer for his suggestions leading to the improvement of this paper.

\section{REFERENCES}

[1] Abel, U. and Ivan, M., New representation of the remainder in the Bernstein approximation, J. Math. Anal. Appl., 381 (2011), No. 2, 952-956

[2] Bărbosu, D., Two dimensional divided differences revisited, Creat. Math. Inform., 17 (2008), No. 1, 1-7

[3] Bărbosu, D. and Pop, O. T., A note on the GBS Bernstein's approximation formula, Annals of the University of Craiova, Math. Comp. Sci. Ser., 35 (2008), 1-6

[4] Bărbosu, D. and Pop, O. T., On the Bernstein bivariate approximation formula, Carpathian J. Math., 24 (2008), No. 3, 293-298

[5] Bărbosu, D. and Pop, O. T., A note on the Bernstein's cubature formula, General Mathematics, 17 (2009), No. 3, 161-172

[6] Bărbosu, D. and Pop, O. T., Bivariate Schurer-Stancu operators revisited, Carpathian J. Math., 26 (2010), No. 1, 24-35

[7] Bărbosu, D. and Ardelean, G., The Bernstein quadrature formula revised, Carpathian J. Math., 30 (2014), No. 3, 275-282

[8] Bernstein, S. N., Démonstration du théorème de Weierstrass fondée sur le calcul de probabilités, Commun. Soc. Math. Kharkow, 13 (1912-1913), No. 2, 1-2

[9] Della Vecchia, B., On the approximation of functions by means of the operators of D. D. Stancu, Studia Univ. Babeş-Bolyai, Mathematica, 37 (1992), No. 1, 3-36

[10] Delvos, F. J. and Schempp, W., Boolean Methods in Interpolation and Approximation, Pitman Research Notes in Mathematics Series 230, Longman Scientific \& Technical, New York, 1989

[11] Gordon, W. J., Distributive lattices and the approximation of multivariate functions, in Proceedings of the Symposium on Approximation with Special Emphasis on Splines, New York, (Schoenberg, I. J., Ed.), Acad. Press, 1969, pp. 223-277

[12] Ionescu, D. V., Divided differences (in Romanian), Ed. Acad. R.S.R., Bucureşti, 1978

[13] Ivan, M., Elements of Interpolation Theory, Mediamira Science Publisher, Cluj-Napoca, 2004

[14] Lupaş, L. and Lupaş, A., Polynomials of binomial type and approximation operators, Studia Univ. Babeş-Bolyai, Mathematica, 32 (1987), No. 4, 61-69

[15] Miclăuş, D., The revision of some results for Bernstein-Stancu type operators, Carpathian J. Math., 28 (2012), No. 2, 289-300

[16] Miclăuş, D., On the GBS Bernstein-Stancu's type operators, Creat. Math. Inform., 22 (2013), No. 1, 81-88

[17] Pop, O. T. and Bărbosu, D., Two dimensional divided differences with multiple knots, An. Şt. Univ. Ovidius Constanţa, 17 (2009), No. 2, 181-190

[18] Popoviciu, T., Sur quelques propriétés des fonctions d'une ou de deux variables réeles, Mathematica, (1934), 1-85

Received: 31.01.2014; In revised form: 03.02.2015; Accepted: 10.02.2015

2010 Mathematics Subject Classification. 41A10, 41A36, 41A80.

Key words and phrases. Bernstein operator, Stancu operator, divided difference, approximation formula, parametric extension, remainder term, upper bound estimation. 
[19] Stancu, D. D., Approximation of functions by a new class of linear polynomial operators, Rev. Roum. Math. Pures et Appl., 13 (1968), 1173-1194

[20] Stancu, D. D., On the remainder of approximation of functions by means of a parameter-dependent linear polynomial operator, Studia Univ. Babeş-Bolyai, Ser. Math.-Mech., 16 (1971), 59-66

TECHNiCAL University OF CluJ-NAPOCA

North University Center at Baia MARE

DePARTMENT OF MATHEMATICS AND COMPUTER SCIENCE

Victoriei 76, 430122 BAiA MARE, ROMANiA

E-mail address: danmiclausrz@yahoo.com 